\title{
Short communication: Grain-induced subacute ruminal acidosis is associated with the differential expression of insulin-like growth factor-binding proteins in rumen papillae of lactating dairy cattle
}

\author{
M. A. Steele, O. AIZahal, M. E. Walpole, and B. W. McBride ${ }^{1}$ \\ Department of Animal and Poultry Science, University of Guelph, Guelph, Ontario, Canada, N1G 2W1
}

\begin{abstract}
The objective of this study was to characterize the mRNA expression of genes involved in the insulin-like growth factor (IGF) axis in the rumen epithelium during grain-induced ruminal acidosis. Eight lactating dairy cattle were randomly assigned to a control $(38 \%$ concentrate) or a high-grain (HG; $57 \%$ concentrate) diet in a randomized study. Dry matter intake, milk production, ruminal $\mathrm{pH}$, and rumen papillae gene expression were measured before treatment allocation (d 0) and on the fourth day of treatment. On d 4, no differences were observed in total feed intake and milk production; however, the cattle fed the $\mathrm{HG}$ diet displayed lower ruminal $\mathrm{pH}(587 \pm 130 \mathrm{~min} / \mathrm{d}$ below 5.6 , mean $\pm \mathrm{SE})$ compared with cattle receiving the control diet (169 \pm $145 \mathrm{~min} / \mathrm{d}$ below 5.6). No change in the relative mRNA expression of $I G F-1$, IGF-1 receptor $(I G F-1 R)$, and IGF-binding protein 6 (IGFBP6) was detected between treatments. However, the relative expression value of IGF-binding protein 3 (IGFBP3) decreased (0.73 \pm 0.07 fold, mean $\pm \mathrm{SE}$ ), whereas IGF-binding protein 5 (IGFBP5) expression increased (1.53 \pm 0.20 fold). These results indicate that the IGF axis may play a role in rumen epithelial adaptation to HG diets.
\end{abstract}

Key words: rumen epithelium, ruminal acidosis, gene expression, insulin-like growth factor

\section{Short Communication}

To meet the energy demands of lactation, dairy cattle in North America are fed high-grain (HG) diets rich in rapidly fermentable carbohydrates ( $>40 \%$ NFC, $\%$ of DM). When dairy cattle are fed HG diets, the rate of rumen fermentation and organic acid production can exceed the rate of rumen absorption and buffering, leading to prolonged periods of depressed ruminal $\mathrm{pH}$. This digestive disorder termed SARA occurs when ruminal $\mathrm{pH}$ is depressed below 5.6 for more than $3 \mathrm{~h}$

Received August 23, 2011.

Accepted June 29, 2012

${ }^{1}$ Corresponding author: bmcbride@uoguelph.ca per day (AlZahal et al., 2007a). Subacute ruminal acidosis has been estimated to occur in $20 \%$ of lactating dairy cattle (Oetzel et al., 1999) and is associated with depressed feed intake and production as well as health ailments such as rumenitis, liver abscesses, laminitis, and whole animal inflammation (Plaizier et al., 2008). Despite the staggering cost to animal performance, health, and welfare little information exists describing how the digestive tract of the dairy cow adapts to grain-induced SARA.

As the rumen epithelium ( $\mathbf{R E}$ ) plays a major role in the absorption and buffering of the organic acid end products of ruminal fermentation, its adaptation may play a role in alleviating the detrimental effects of SARA. It is well recognized that rumen papillae increase in size when ruminants are transitioned to an HG diet, thereby increasing the surface area for absorption (Goodlad, 1981; Odongo et al., 2006). Recently, it has been shown that the RE undergoes rapid structural and functional adaptations during the first week of graininduced SARA that are associated with the differential expression of genes (Steele et al., 2011a,b).

The precise signaling mechanisms that orchestrate $\mathrm{RE}$ adaptation and growth are still unclear; however, evidence is mounting that the IGF axis may play a role. For example, peripheral circulating IGF-1 concentrations increase when dietary energy intake increases in ruminants (Shen et al., 2004). It has been shown that IGF-1 increases in vitro RE cell proliferation (Baldwin, 1999). Insulin-like growth factor-1 binds to the IGF-1 receptor (IGF-1R), a tyrosine kinase receptor, which elicits a cell-signaling cascade to promote the transcription of protein kinases that favor tissue growth (Kaulfuß et al., 2009). The binding of IGF-1 to IGF$1 \mathrm{R}$ is modulated by a family of IGF-binding proteins (IGFBP) expressed in tissue (Firth and Baxter, 2002). In a recent microarray study, the differential mRNA expression of IGFBP3, IGFBP 5, and IGFBP 6 was detected in rumen papillae during grain-induced SARA in nonlactating cattle (Steele et al., 2011a). Therefore, the aim of the present study was to further investigate whether the mRNA expression of genes involved in the IGF axis in rumen papillae are altered in lactating 
dairy cattle during the early stages of grain-induced SARA. It was hypothesized that mRNA expression of the IGFBP would be altered in rumen papillae during the early stages of SARA in lactating dairy cattle.

All experimental procedures for this study were approved by the University of Guelph Animal Care Committee in accordance with the Canadian Council on Animal Care (1993). Eight lactating Holstein dairy cattle (586 $\pm 37 \mathrm{~kg}$ of BW; mean $\pm \mathrm{SD})$ in their second lactation (77 \pm 18 DIM; mean $\pm \mathrm{SD}$ ) were used in a randomized study. A rumen cannula was fitted during the dry period before the beginning of their second lactation. All cattle were housed in a tiestall facility at the Ponsonby Dairy Research Station (University of Guelph, Guelph, ON, Canada). Throughout their lactation, the cattle were milked twice daily in their stalls at 0600 and $1600 \mathrm{~h}$ and had unlimited access to water and a lactating dairy cattle TMR (Table 1; CON diet) that was fed at 0800 and $1600 \mathrm{~h}$ (one-third and two-thirds of daily allotment, respectively).

Dry matter intake and milk production were measured throughout the experiment. For the week preceding the experiment, the DMI of the cattle was measured on a daily basis and the mean value $+10 \%$ was

Table 1. Ingredient composition and chemical analyses of the control $(\mathrm{CON})$ and high-grain (HG) diet

\begin{tabular}{lrr}
\hline Composition & CON & HG \\
\hline Ingredient/TMR, \% of DM & & \\
Corn silage & 34.0 & 23.8 \\
Alfalfa silage & 21.3 & 14.9 \\
Straw & 6.4 & 4.4 \\
High-moisture corn & 17.0 & 11.9 \\
Grain mix pellets $^{1}$ & 0.0 & 30.0 \\
Protein supplement $^{2}$ & 21.0 & 14.9 \\
Chemical composition $_{\text {DM, \% }}$ & 43.8 & 51.0 \\
CP (N $\times$ 6.25), \% of DM & 17.0 & 15.6 \\
Soluble protein, \% of CP & 35.5 & 33.8 \\
ADF, \% of DM & 19.8 & 15.4 \\
NDF, \% of DM & 32.8 & 27.5 \\
Ash, \% of DM & 7.1 & 5.6 \\
NFC, \% of DM & 40.2 & 50.3 \\
Starch, \% of DM & 19.6 & 30.6 \\
NE ${ }_{\mathrm{L}}{ }^{5}$ Mcal/kg & 1.7 & 1.8 \\
\hline
\end{tabular}

${ }^{1}$ Comprised $40 \%$ ground wheat, $40 \%$ ground barley, and $20 \%$ ground corn.

${ }^{2}$ Contained (\% as-fed basis): $48 \%$ soybean meal, 29.1 ; canola meal, 15.0; roasted soybean (whole), 15.0; dried distillers grain, 12.5; highprotein corn gluten meal, 5.0; beet pulp, 5.0; fish meal (herring), 2.5; calcium carbonate (limestone), 3.6; monocalcium phosphate, 2.0; tallow, 2.0; sodium sesquicarbonate, 2.5; salt, 2.3; molasses (in pelleter), 2.0; magnesium oxide, 0.7; Organic Ruminant Micro Premix (Floradale Feed Mill Ltd., Floradale, ON, Canada), 0.5; and sulfur flour $(99.5 \%), 0.1$.

${ }^{3} \mathrm{NFC}=100-(\mathrm{NDF}+\mathrm{CP}+$ ether extract + ash $)$.

${ }^{4}$ Analyzed according to Hall (2000).

${ }^{5}$ Estimated according to NRC (2001) using the chemical analysis of feed ingredients. offered throughout the experiment. Papillae biopsies were collected on d 0 from the ventral sac at $2000 \mathrm{~h}$, as it was established from previous experiments with similar feeding protocols to be the time of maximal ruminal fermentation (Steele et al., 2011a,b). Biopsied rumen papillae were washed 10 times in PBS (pH 7.4), frozen in liquid nitrogen, and stored at $-80^{\circ} \mathrm{C}$ until RNA isolation. Ruminal $\mathrm{pH}$ electrodes were calibrated before each reading and $\mathrm{pH}$ was measured every minute (AlZahal et al., 2007b) for $24 \mathrm{~h}$ in the ventral sac region of the rumen before rumen papillae biopsies on $\mathrm{d} 0$.

On d 1, cows were randomly assigned to either continue receiving the CON diet or be transitioned in 1 $\mathrm{d}$ to an HG diet in which $30 \%$ of the CON diet was substituted with grain mix pellets (Table 1). The grain mix pellets fed to the $\mathrm{HG}$ cattle comprised $40 \%$ ground wheat, $40 \%$ ground barley, and $20 \%$ ground corn and was offered separately from the TMR in trays in equal amounts at 0800,1200 , and $1600 \mathrm{~h}$. Grain pellets that were not consumed within $30 \mathrm{~m}$ of feeding were added to the rumen through the cannula and mixed by hand with rumen contents. On d 4 of the experiment, rumen papillae were biopsied at $2000 \mathrm{~h}$ and continuous ruminal $\mathrm{pH}$ was measured for $24 \mathrm{~h}$ before the biopsies.

Total RNA was isolated using an RNeasy midi kit (Qiagen Inc., Mississauga, ON, Canada) from approximately $100 \mathrm{mg}$ of rumen tissue. The RNA concentration was determined using a NanoDrop spectrophotometer (ND-1000; NanoDrop Technologies LLC, Wilmington, DE) and the 260:280 ratio was determined for all samples to be between 1.8 and 2.1. Ribonucleic acid was then treated with DNase (Invitrogen Canada Inc., Burlington, ON, Canada) before assessing the quality using an Agilent 2100 Bioanalyzer (Agilent Technologies Inc., Palo Alto, CA) and the RNA 6000 Nano kit (Caliper Life Sciences Inc., Mountain View, CA). The RNA integrity number of all of the samples was determined to be $7.3 \pm 0.2$ (mean $\pm \mathrm{SD}$ ).

To assess mRNA expression of $I G F-1, I G F-1 R$, IGFBP3, IGFBP5, and IGFBP6, RNA samples (500 ng each) were reverse-transcribed using the high-capacity cDNA reverse transcription kit (Applied Biosystems, Streetsville, ON, Canada). The Power SYBR Green PCR master mix was used to perform quantitative PCR in duplicate using an ABI Prism 7000 (Applied Biosystems). The quantitative PCR primers for each gene were validated in previous studies and the sequences, amplicon size, and primer efficiencies are presented in Table 2. Based on previous experimental protocols (Steele et al., 2011b), GAPDH was determined to be the most stable housekeeping gene in rumen papillae and was, therefore, used in this study. Relative gene expression for each cow was calculated using the $\Delta \Delta \mathrm{C}_{\mathrm{t}}$ (where $\mathrm{C}_{\mathrm{t}}=$ cycle threshold) method (Pfaffl, 2001). All 
Table 2. Primers for quantitative real-time PCR

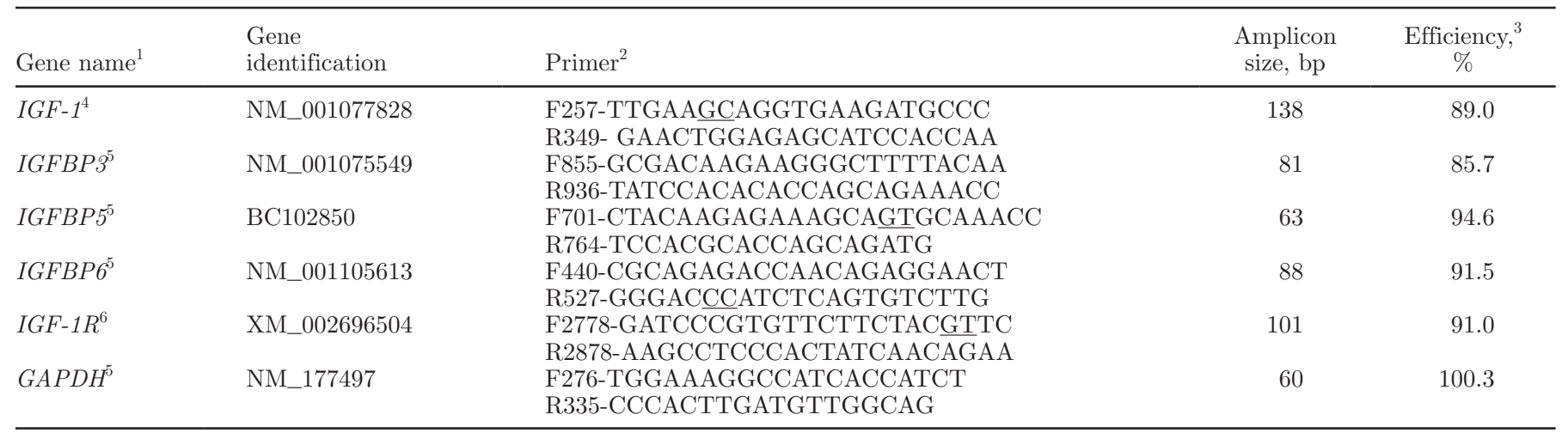

${ }^{1} I G F B P 3=$ IGF-binding protein 3; IGFBP5 = IGF-binding protein 5; IGFBP6 = IGF-binding protein 6; IGF-1R= IGF-1 receptor.

${ }^{2}$ Exon junctions underlined; $\mathrm{F}=$ forward; $\mathrm{R}=$ reverse.

${ }^{3}$ The PCR efficiency $(\mathrm{E})$ was calculated as follows: $\mathrm{E}=-1+10^{(-1 / \text { slope })} \times 100$; the slope was obtained by the 5 -point standard curve with an $\mathrm{R}^{2}$ of 0.99 .

${ }^{4} \mathrm{PCR}$ primers validated in Loor et al. (2007).

${ }^{5} \mathrm{PCR}$ primers validated in Steele et al. (2011a).

${ }^{6} \mathrm{PCR}$ primers validated in Fenwick et al. (2008).

cattle had the perfect mean of 1.0 at $\mathrm{d} 0$ and the mean change in expression for d 4 in CON-diet cattle was compared with the individual expression values of HGdiet cattle.

All parameters were analyzed using PROC MIXED of SAS (SAS Institute, 2004). Dry matter intake, milk production, time below ruminal $\mathrm{pH} 5.6$, and real-time PCR were analyzed using the following model:

$$
\mathrm{Y}_{\mathrm{ijk}}=\mu+\mathrm{D}_{\mathrm{i}}+\mathrm{T}_{\mathrm{j}}+(\mathrm{D} \times \mathrm{T})_{\mathrm{ij}}+\varepsilon_{\mathrm{ijk}},
$$

where $Y_{\mathrm{ijk}}$ is the dependent variable, $\mu$ is the overall mean, $D_{i}$ is the fixed effect of diet ( $i=1$ or 2$), T_{j}$ is the fixed effect of time or day $(\mathrm{j}=1$ or 2$),(\mathrm{D} \times \mathrm{T})_{\mathrm{ij}}$ is the effect of the interaction of diet by time $(\mathrm{ij}=1, \ldots, 8)$, and $\varepsilon_{\mathrm{ijk}}$ is the random residual error. Day of experiment was used as a repeated measurement with cow as the subject. Effects were considered significant at $P<0.10$.

The feed intake and milk production of cattle on $\mathrm{d}$ 0 of the experiment were $38.4 \pm 2.1 \mathrm{~kg}$ and $24.2 \pm 0.7$ $\mathrm{kg}$ (mean $\pm \mathrm{SE})$, respectively. Despite an increase $(P<$ 0.01 ) in starch intake on d 4 in HG-diet compared with CON-diet cattle $(6.89 \pm 0.23$ vs. $4.78 \pm 0.27 \mathrm{~kg})$, total feed intake, milk production, and milk components were not different on d 4 of the experiment. Previous studies investigating SARA typically report depressed feed intake, production, and milk fat percentage and increased milk protein percentage (Plaizier et al., 2008). It is possible that the duration of time consuming the HG diet in this study was too brief (4 d) to elicit a detectable feed intake and milk production response that is commonly reported in lactating dairy cattle.
In spite of no differences between treatment for feed intake and milk production being detected, ruminal $\mathrm{pH}$ was responsive to treatment. On $\mathrm{d} 0$, when both groups were consuming the $\mathrm{CON}$ diet, the mean ruminal $\mathrm{pH}$ was $163 \pm 57 \mathrm{~min} / \mathrm{d}$ below 5.6. Ruminal $\mathrm{pH}$ was significantly different between treatments on d 4 as ruminal $\mathrm{pH}$ decreased to $580 \pm 130 \mathrm{~min} / \mathrm{d}$ below 5.6 in HGdiet cattle (Figure 1A). The minimum daily ruminal $\mathrm{pH}$ was also significantly lower in the HG-diet cattle $(5.00 \pm 0.03$ vs. $5.36 \pm 0.15$, mean $\pm \mathrm{SE})$. The degree of ruminal acidosis induced in this study was severe compared with most SARA studies that substitute a similar portion of the TMR with grain pellet (Keunen et al., 2002; Khafipour et al., 2009).

The overall objective of this study was to determine how the expression of genes involved in the IGF axis responds to the early onset of grain-induced ruminal acidosis. This experiment was unique compared with previous studies, as rumen papillae biopsies were collected during the early stages of the grain challenge (d 4) and during daily peak fermentation $(2000 \mathrm{~h}, 4 \mathrm{~h}$ after final meal). The differential expression of IGFBP3 and IGFBP 5 was detected between treatments on $\mathrm{d} 4$ of the experiment (Figure 1B). The relative expression of $I G F B P 3$ was decreased $(P=0.05,0.73 \pm 0.07$ fold, mean $\pm \mathrm{SE}$ ) and, conversely, IGFBP5 was increased $(P=0.08,1.53 \pm 0.20$ fold $)$. This is the third study that has shown differential expression of IGFBP3 and $I G F B P 5$ in dairy cattle challenged with grain-induced SARA. By contrast, no change in the relative mRNA expression of $I G F-1, I G F-1 R$, and IGFBP 6 was detected between treatments (Figure 1B). The lack of 

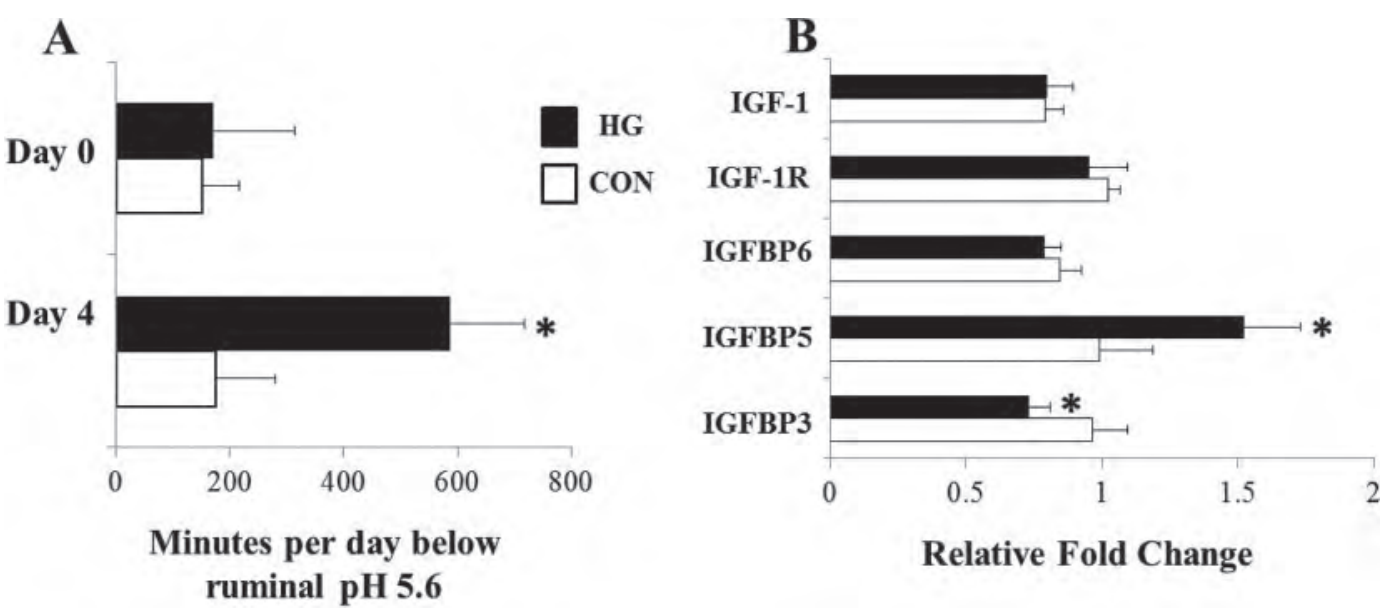

Figure 1. Summarized ruminal $\mathrm{pH}$ and gene expression results: (A) minutes per day below ruminal pH of 5.6 during d 0 (baseline) and d 4 of treatment for the control $(\mathrm{CON})$ and high-grain $(\mathrm{HG})$ diet cattle; (B) relative expression of $I G F-1$, IGF-1 receptor (IGF-1R), IGF-binding protein (IGFBP) 6 (IGFBP6), IGFBP5, and IGFBP3 mRNA on d 4 between CON- and HG-diet cattle on d 4 . Values are means \pm SEM $(\mathrm{n}=$ 4) expressed as minutes per day and fold change relative to baseline. Asterisks $\left(^{*}\right)$ denote differences between treatments $(P<0.10)$.

differential gene expression of $I G F-1$ and $I G F-1 R$ is in agreement with a study on goats that were transitioned to a high-energy diet (Shen et al., 2004). However, the lack of response of $I G F B P 6$ was not in agreement with a previous experiment in nonlactating dairy cattle in which a downregulation was detected during graininduced ruminal acidosis (Steele et al., 2011a).

It has been established that the RE adapts to a grain challenge by increasing tissue growth, thus increasing the surface area of absorption and buffering of organic acids. In the case of mechanisms involved in $\mathrm{RE}$ growth, research is mounting that suggests that the IGF axis is involved. Increasing dietary energy intake is associated with higher concentrations of circulating IGF-1 in the blood of the ruminant (Shen et al., 2004). However, IGF-1 must bind to IGF-1R to elicit its growth response, which is modulated by IGFBP that are expressed in tissues sensitive to IGF-1 (Firth and Baxter, 2002).

The control of IGF-1 events by IGFBP have been characterized in other cell models in the dairy cow, the most noteworthy being proliferation in bovine mammary epithelial cells (McGuire et al., 1992). Insulin-like growth factor-binding proteins influence the success of IGF-1 binding to IGF-1R, and specific IGFBP have specialized actions and their functions can oppose each other. For example, it has been well characterized that IGFBP3 opposes IGF-1 events; therefore, its downregulation may encourage cellular growth in the RE (Albiston et al., 1992). Contrastingly, IGFBP5 potentiates IGF-1 events; therefore, its upregulation may stimulate proliferation (Firth and Baxter, 2002).

The expression of IGFBP in small and large intestinal cell lines has been shown to be modulated by short-chain fatty acids, in particular butyrate (Sanderson, 2004). In a study investigating bovine kidney epithelial cell gene expression, butyrate induced changes in expression of several IGFBP (Li and Li, 2006). Additionally, in mice, intestinal epithelial cells butyrate downregulated the expression of $I G F B P 3$, which blocked apoptosis (Sanderson, 2004). Interestingly, Mentschel et al. (2001) also found that ruminal butyrate decreased apoptosis in the $\mathrm{RE}$ of calves; however, the expression of genes was not measured. Thus, IGFBP expression may control RE growth independent of the level of IGF-1 in circulation during a grain challenge.

Evidence continues to accumulate linking rumen papillae functional adaptations with the IGF axis. In review, the present study confirms previous mRNA expression signatures detected in rumen papillae during the early onset of grain-induced ruminal acidosis. The results of this study suggest that the response of the IGF-1 axis may be regulated by its binding proteins expressed locally in rumen tissue. Further investigations on how the IGF axis interacts to adapt rumen epithelial growth to the energy density of the diet have the potential to greatly improve our understanding of adaptive mechanisms of the dairy cow during ruminal acidosis.

\section{ACKNOWLEDGMENTS}

We acknowledge the continued support received from Dairy Farmers of Ontario (Mississauga, ON, Canada) and the Natural Sciences and Engineering Research Council of Canada (Ottawa, ON, Canada; B. W. McBride). We also appreciate the technical help provided by Jing Zhang (University of Guelph Genomics Facil- 
ity, Guelph, ON, Canada), Laura Wright (University of Guelph Elora Dairy Research Centre, Elora, ON, Canada), and the staff at the Ponsonby Dairy Research Station (University of Guelph).

\section{REFERENCES}

Albiston, A. L., R. G. Taylor, A. C. Herington, D. J. Beveridge, and P. J. Fuller. 1992. Divergent ileal IGF-I and IGFBP-3 gene expression after small bowel resection: A novel mechanism to amplify IGF action. Mol. Cell Endocrinol. 83:R17-R20.

AlZahal, O., E. Kebreab, J. France, and B. W. McBride. 2007a. Mathematical approach to predicting biological values from ruminal $\mathrm{pH}$ measurements. J. Dairy Sci. 90:3777-3785.

AlZahal, O., B. Rustomo, N. E. Odongo, T. F. Duffield, and B. W McBride. 2007b. Technical note: A system for continuous recording of ruminal pH measurements. J. Anim. Sci. 85:213-217.

Baldwin, R. L. 1999. The proliferative actions of insulin, insulin-like growth factor-I, epidermal growth factor, butyrate and propionate on ruminal epithelial cells in vitro. Small Rumin. Res. 32:261-268.

Canadian Council on Animal Care. 1993. Guide to the Care and Use of Experimental Animals. Vol. 1. E. D. Olfert, B. M. Cross, and A. A. McWilliams, ed. Canadian Council on Animal Care (CCAC), Ottawa, Ontario, Canada.

Fenwick, M. A., R. Fitzpatrick, D. A. Kenny, M. G. Diskin, J. Patton, J. J. Murphy, and D. C. Wathes. 2008. Interrelationships between negative energy balance (NEB) and IGF regulation in liver of lactating dairy cows. Domest. Anim. Endocrinol. 34:31-44.

Firth, S. M., and R. C. Baxter. 2002. Cellular actions of the insulinlike growth factor binding proteins. Endocr. Rev. 23:824-854.

Goodlad, R. A. 1981. Some effects of diet on the mitotic index and the cell cycle of the ruminal epithelium of sheep. Q. J. Exp. Physiol. 66:487-499.

Hall, M. B. 2000. Starch gelatinization and hydrolysis method. Pages 29-38 in Neutral Detergent Soluble Carbohydrates, Nutritional Relevance and Analysis - A Laboratory Manual. Dept. Animal Science, Univ. Florida, Gainesville.

Kaulfuß, S., P. Burfeind, J. Gaedcke, and J. G. Scharf. 2009. Dual silencing of insulin-like growth factor-I receptor and epidermal growth factor receptor in colorectal cancer cells is associated with decreased proliferation and enhanced apoptosis. Mol. Cancer Ther. 8:821-833.

Keunen, J. E., J. C. Plaizier, L. Kyriazakis, T. F. Duffield, T. M. Widowski, M. I. Lindinger, and B. W. McBride. 2002. Effects of a subacute ruminal acidosis model on the diet selection of dairy cows. J. Dairy Sci. 85:3304-3313.

Khafipour, E., D. O. Krause, and J. C. Plaizier. 2009. A grain-based subacute ruminal acidosis challenge causes translocation of lipo- polysaccharide and triggers inflammation. J. Dairy Sci. 92:10601070.

Li, R. W., and C. Li. 2006. Butyrate induces profound changes in gene expression related to multiple signal pathways in bovine kidney epithelial cells. BMC Genomics 7:234.

Loor, J. J., R. E. Everts, M. Bionaz, H. M. Dann, D. E. Morin, R. Oliveira, S. L. Rodriguez-Zas, J. K. Drackley, and H. A. Lewin. 2007. Nutrition-induced ketosis alters metabolic and signaling gene networks in liver of periparturient dairy cows. Physiol. Genomics 32:105-116.

McGuire, M. A., J. L. Vicini, D. E. Bauman, and J. J. Veenhuizen. 1992. Insulin-like growth factors and binding proteins in ruminants and their nutritional regulation. J. Anim. Sci. 70:2901-2910.

Mentschel, J., R. Leiser, C. Mulling, C. Pfarrer, and R. Claus. 2001. Butyric acid stimulates rumen mucosa development in the calf mainly by a reduction of apoptosis. Arch. Tierernähr. 55:85-102.

NRC. 2001. Nutrient Requirements of Dairy Cattle. 7th rev. ed. Natl. Acad. Sci., Washington, DC.

Odongo, N. E., O. AlZahal, M. I. Lindinger, T. F. Duffield, E. V. Valdes, S. P. Terrell, and B. W. McBride. 2006. Effects of mild heat stress and grain challenge on acid-base balance and rumen tissue histology in lambs. J. Anim. Sci. 84:447-455.

Oetzel, G. R., K. V. Nordlund, and E. F. Garrett. 1999. Effect of ruminal $\mathrm{pH}$ and stage of lactation on ruminal lactate concentrations in dairy cows. J. Dairy Sci. 82(Suppl. 1):38. (Abstr.)

Pfaffl, M. W. 2001. A new mathematical model for relative quantification in real-time RT-PCR. Nucleic Acids Res. 29:e45.

Plaizier, J. C., D. O. Krause, G. N. Gozho, and B. W. McBride. 2008. Subacute ruminal acidosis in dairy cows: The physiological causes, incidence and consequences. Vet. J. 176:21-31.

Sanderson, I. R. 2004. Short chain fatty acid regulation of signaling genes expressed by the intestinal epithelium. J. Nutr. 134:2450S$2454 \mathrm{~S}$.

SAS Institute. 2004. SAS/STAT Users Guide. Release 9.1. SAS Inst. Inc., Cary, NC.

Shen, Z., H. M. Seyfert, B. Löhrke, F. Schneider, R. Zitnan, A. Chudy, S. Kuhla, H. A. Hammon, J. W. Blum, H. Martens, H. Hagemeister, and J. Voigt. 2004. An energy-rich diet causes rumen papillae proliferation associated with more IGF type 1 receptors and increased plasma IGF-1 concentrations in young goats. J. Nutr. 134:11-17.

Steele, M. A., J. Croom, M. Kahler, O. AlZahal, S. E. Hook, K. Plaizier, and B. W. McBride. 2011a. Bovine rumen epithelium undergoes dramatic structural adaptations during grain-induced subacute ruminal acidosis. Am. J. Physiol. Regul. Integr. Comp. Physiol. 300:R1515-R1523.

Steele, M. A., G. Vandervoort, O. AlZahal, S. E. Hook, J. C. Matthews, and B. W. McBride. 2011b. Rumen epithelial adaptation to high-grain diets involves the coordinated regulation of genes involved in cholesterol homeostasis. Physiol. Genomics 43:308-316. 